
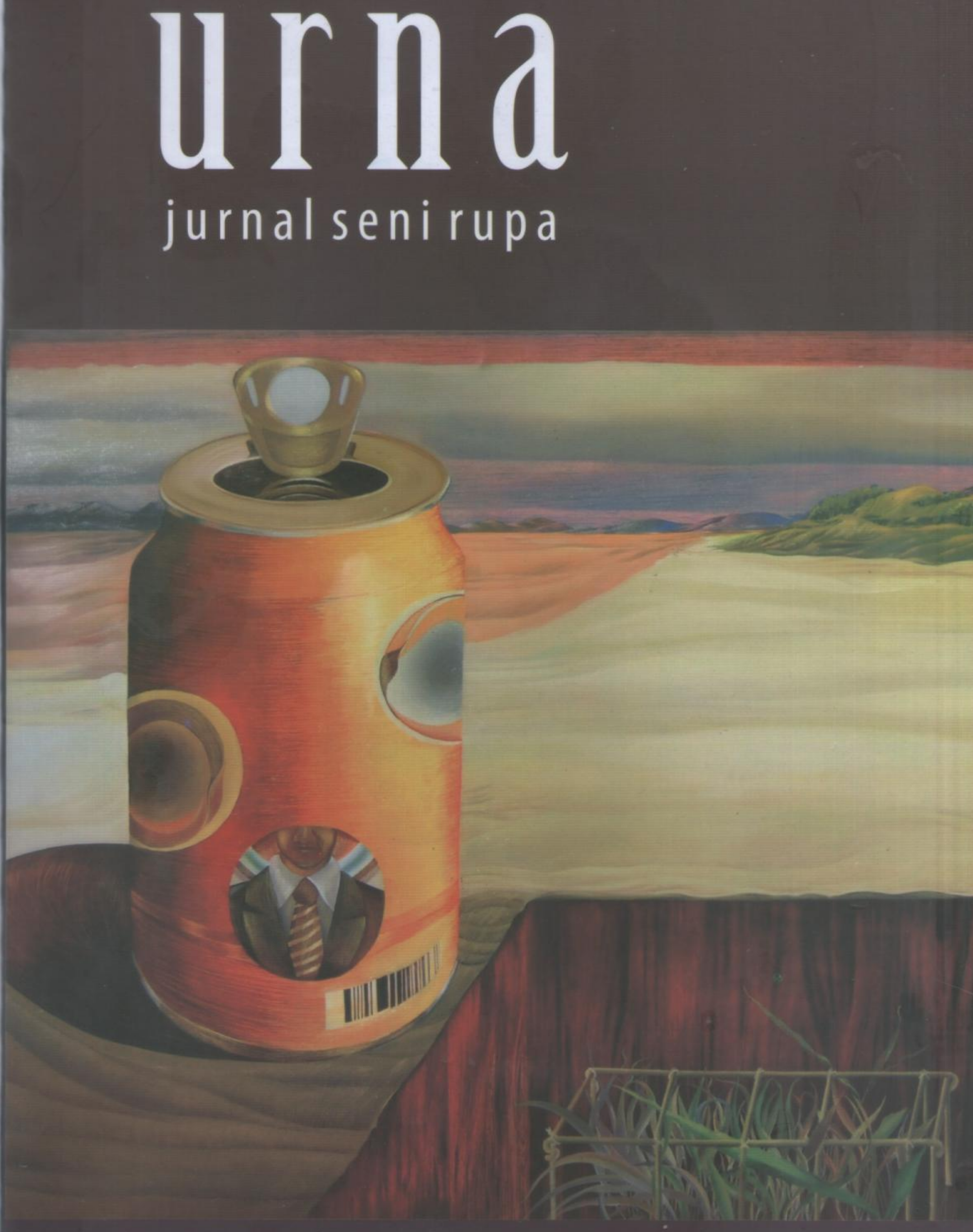

Jurusan Pendidikan Seni Rupa | Universitas Negeri Surabaya 
121 TANPA SENI ANDA TIDAK EKSIS!

TELAAH KONSUMSI SENI MASYARAKAT URBAN

Michael HB Raditya (Universitas Gadjah Mada)

137 ESTETIKA HINDU DI ERA GLOBALISASI

I Nyoman Lodra (Universitas Negeri Surabaya)

145 IKONOGRAFI SENI PATUNG TRADISIONAL NUSANTARA DALAM SENI PATUNG INDONESIA MODERN

Nur Wakhid (Universitas Negeri Surabaya)

153 PENGEMBANGAN DESAIN KERAJINAN DI BALI (RAGAM DESAIN PADA KAIN SONGKET)

A.A I Ngurah Marhaeni, dkk (Universitas Pendidikan Ganesha)

163 AKSIOLOGI DALAM TEKNOLOGI FOTOGRAFI, ILMU DAN TANGGUNG JAWAB SOSIAL ILMUWAN

I Wayan Swandi (Institut Seni Indonesia Denpasar)

173 FOTO BRANDING SENAYAN CITY: KAJIAN SEMIOTIKA FOTOGRAFI Eko Budhi Susanto (Institut Teknologi Bandung)

191 KARAKTERISTIK KARYA LUKISAN A. ARIFIN

Nessya Fitroyana (Institut Seni Indonesia Yogyakarta)

207 PENCIPTAAN KARYA DRAWING MENGGUNAKAN SOFTWARE ADOBE ADOBE FLASH CS. 6

Tri Cahyo K \& Winarno (Universitas Negeri Surabaya)

222 PENGEMBANGAN DESAIN SABLON KAOS BERBASIS SENI BUDAYA NUSANTARA

Asidigisianti, Marsudi, Nova Kristiana (Universitas Negeri Surabaya)

236 MODEL TERBALIK DAPAT MENINGKATKAN KEMAMPUAN MENGGAMBAR BENTUK PADA MAHASISWA PROGRAM STUDI

D3 DESAIN GRAFIS ANGKATAN 2011

Siti Mutmainah \& M. Sattar (Universitas Negeri Surabaya) 


\title{
PENGEMBANGAN DESAIN SABLON KAOS BERBASIS SENI BUDAYA NUSANTARA
}

\author{
Asidigisianti Surya Patria, Marsudi, Nova Kristiana
}

\begin{abstract}
ABSTRAK: Penelitian ini merupakan penelitian pengembangan, yakni dalam proses penelitian menggunakan alur dan prosedur penelitian pengembangan. Prosedur penelitian tersebut adalah; mengumpulkan data, analisis kebutuhan, merumuskan tujuan, mengembangkan desain. Hasil yang diharapkan merupakan hasil penerapan desain melalui kegiatan mencetak dengan menerapkan desain yang telah dirancang dalam media kaos dengan teknik cetak saring/sablon. Pengkategorian karya sablon kaos yang dianalisis dengan tema: seni pertunjukkan tradisional, seni rupa tradisional, mainan tradisional, upacara adat dan makanan tradisional. Seni Pertunjukkan tradisional diwakili oleh Reog Ponorogo, Seni Rupa Tradisional diwakili dengan topeng Tari Kelana, Mainan Tradisional diwakili dengan permainan Gasing, Sedangkan upacara adat diwujudkan dengan tumpeng.
\end{abstract}

Kata Kunci: Perancangan, Desain Sablon Kaos, Seni Budaya Nusantara

\begin{abstract}
This is a development research which used the development procedure. The steps are: collecting data which are the T-shirt design of the student of Graphic Design UNESA, then compiling need assessment, targeting the goal finally developing the design. The result of the research is the implementation of the t-shirt designs which were created before into the screening technique into the $\mathrm{t}$-shirt. The categorization of the $\mathrm{t}$-shirt designs which were analyzed divided into: traditional performance show, traditional art, traditional toys and culture ceremony. The traditional performance show represented by Reog Ponorogo, the traditional art represented by Klana Mask, the traditional toys represented by Gasing and the culture ceremony represented by Sedekah Bumi (Tumpeng).
\end{abstract}

Key word: Design, T-Shirt Design, Nusantara, Art dan Culture.

Kekayaan seni dan budaya Indonesia merupakan perwujudan keragaman seni budaya Nusantara yang berbasis seni dan budaya lokal. Ragam seni budaya Nusantara merupakan kebanggaan sekaligus kewajiban bagi bangsa dan masyarakat Indonesia untuk melestarikan melalui pewarisan nilai-nilai seni budaya serta menjaga dari dampak pergeseran seni budaya modern yang kian tanpa batas. Hasil cipta rasa dan karya dalam berbagai adat dan ragam seni budaya yang dimiliki oleh bangsa Indonesia ini seringkali dilirik oleh bangsa lain dan beberapa diantaranya telah diklaim menjadi karya seni budaya bangsa lain.

Keragaman seni dan budaya atau "art and cultural diversity" adalah keniscayaan yang tidak dapat dipungkiri keberadaannya. Dalam konteks masyarakat majemuk, selain seni dan budaya kelompok dalam berbagai sukubangsa, seni budaya masyarakat Indonesia merupakan kumpulan seni dan budaya daerah yang bersifat kewilayahan yang merupakan akar seni dan budaya nusantara yang saling mengisi dan menghargai antara satu dengan 
yang lainnya dalam konteks kebhinekaan. Sejarah membuktikan bahwa dalam sudut pandang seni dan budaya, masyarakat Indonesia mampu hidup secara berdampingan, saling mengisi, dan ataupun berjalan secara paralel. Misalnya seni dan budaya tradisional berdiri sejalan secara paralel dengan kebudayaan kebudayaan masyarakat urban yang merupakan simbol kekinian dalam konteks seni budaya modern. Namun demikian, jika seni dan budaya tradisi tersebut generasi pewarisnya kian hilang, maka pada saatnya bangsa kita akan kehilangan jatidirinya, sebagai bangsa yang kaya akan seni dan budaya tradisi.

Program pelestarian dan pewarisan nilai-nilai seni dan budaya merupakan bagian terpenting yang akan menjamin keberlangsungan seni dan budaya nusantara yang berbasis seni tradisi. Namun demikian, pewarisan nilai-nilai seni dan budaya tersebut tidak mudah sebagai akibat tidak terbendungnya kebudayaan modern yang kian digandrungi para generasi muda. Sachari (2002:5-6) berpendapat bahwa lemahnya program pewarisan nilai diperparah juga dengan adanya para kaum cerdik pandai dan para pelaku media selalu mengagung-agungkan kebudayaan asing secara berlebihan. Masyarakat akademis cenderung meninggalkan "sejarah intelektual" bangsanya sendiri, sehingga mempengaruhi pandangan dan penghargaan masyarakat terhadap karya-karya budaya sendiri. Hal ini menyebabkan lambat laun artefak dan karya pikiran bangsa Indonesia menjadi semakin asing di negerinya sendiri.

Sumber-sumber kajian nilai budaya masih sedikit dikaji dan sering terlupakan dalam proses pembelajaran. Pentingnya penyerapan nilai-nilai budaya dalam upaya pembentukan sikap bangga terhadap seni budaya sendiri, harus diimplementasikan dalam setiap jenjang pendidikan. Sulitnya mengajarkan apresiasi terhadap seni dan budaya tradisi merupakan gejala yang muncul akibat pergeseran budaya tradisi ke budaya modern ditandai ketergantungan manusia terhadap teknologi. Kondisi inilah yang menyebabkan para generasi muda mulai meninggalkan seni dan budaya tradisional dan beralih ke dunia modern yang serba cepat dan instan tanpa batas dan jarak.

Jurusan pendidikan seni rupa merupakan program studi yang memiliki visi unggul dalam pendidikan seni rupa, kukuh dalam keilmuan seni rupa yang berbasis pada keunggulan budaya visual Nusantara. Visi ini selanjutnya menjadi keunggulan serta penciri yang diwujudkan dalam pembelajaran. Kaitannya dengan pelestarian seni dan budaya nusantara, mengacu pada visi dan misi jurusan, proses pembelajaran di Jurusan Seni Rupa 
Program Studi Pendidikan Seni Rupa dan Desain Grafis senantiasa bertujuan mengembangkan nilai-nilai seni dan budaya nusantara dalam apresiasi maupun kreasi.

Dalam usaha menumbuhkembangkan sikap positif mahasiswa pendidikan seni rupa dan desain grafis, apresiasi terhadap seni dan budaya nusantara dapat diimplementasikan melalui kegiatan perkuliahan yang diakhiri kegiatan penciptaan karya yang berbasis pada seni dan budaya nusantara. Melalui penciptaan karya seni rupa dan desain yang bertemakan seni dan budaya nusantara, khususnya seni budaya tradisi, mahasiswa diharapkan dapat mengenali ragam seni budaya nusantara. Selanjutnya mahasiswa dapat mengembangkan gagasanya yang diwujudkan dalam konsep desain melalui penggalian data terkait seni budaya nusantara.

Budaya berasal dari bahasa Sansekerta buddayah, yaitu bentuk jamak dari kata buddhi yang berarti budi akal. Ada sarjana lain yang mengupas kata budaya sebagai suatu perkembangan dari kata majemuk budi-daya yang berarti daya dan budi. Oleh sebab itu ada perbedaan "budaya" dan "kebudayaan". "Budaya" adalah daya dan budi yang berupa cipta, karsa dan rasa. Seangkan "kebudayaan" adalah hasil dari cipta, rasa dan karsa. Dalam istilah antrpologi budaya kedua istilah tersebut adalah sama. Budaya merupakan kependekan dari kebudayaan (Koentjaningrat, 2009:146)

Honigman (dalam Koentjaningrat, 2009:150) membedakan adanya tiga gejala kebudayaan yaitu: ideas, activities, dan artifact, kemudian dijabarkan oleh Koentjaningrat dalam tiga wujud kebudayaan, berupa: 1) Wujud kebudayaan sebagai suatu kompleks dari ide, gagasan, nilai, norma, peraturan dan sebagainya. 2) Wujud kebudyaan sebagai kompleks aktivitas serta tindakan berpola dari manusia dalam masyarakat. 3)Wujud kebudayaan sebagai benda-benda hasil karya manusia.

Unsur kebudayaan universal merupakan unsur kebudayaan yang bersifat universal dan dapat dijumpai dalam semua kebudayaan bangsa ataupun suku diamanapun di dunia. Dengan mengambil sari dari berbagai sarajana antropologi maka Koentjaningrat (2009:164) berpedapat bahwa terdapat tujuh unsur kebudayaan yang dapat ditemukan pada semua bangsa di dunia. Ketujuh unsure yan dapat disebut sebagai isi pokok kebudayaan di dunia adalah: Bahasa, Sistem Pengetahuan, Organisasi social, Sistem peralatan hidup dan teknologi, Sistem mata pencaharian hidup, Sistem religi, dan kesenian. 
Dalam proses apresiasi, nilai budaya memiliki kedudukan yang sangat penting, karena dengan nilai tersebut akan berimplikasi pada sikap dan perilaku sebagai tujuan akhir dalam pembelajaran. Menurut Gustami, (2007:364) nilai tradisi merupakan kristalisasi makna hidup masa silam yang masih lestari. Ekspresi modern merupakan ungkapan makna hidup sesuai zamannya. Walau keduanya bertujuan untuk kebahagiaan hidup manusia, namun masing-masing memiliki spirit, ruh, dan jiwa yang berbeda. Kehidupan tradisional diliputi alam pikir metafisika didukung teknologi sederhana, sedangkan kehidupan modern ditandai dengan kemajuan ilmu pengetahuan, didukung teknologi canggih.

\section{Metode}

Jenis penelitian ini adalah penelitian pengembangan produk (Research and product development) merupakan proses mengembangkan produk yang sudah ada secara bertanggungjawab dalam rangka meningkatkan kepuasan konsumen. Sukmadinata (2005:164) mengatakan 'penelitian dan Pengembangan adalah suatu proses atau langkahlangkah untuk mengembangkan suatu produk baru atau menyempurnakan produk produk yang telah ada, yang dapat dipertanggungjawabkan. Kegiatan research tidak hanya dilakukan pada tahap needs assesment, tapi juga pada proses pengembangan produk, yang memerlukan kegiatan pengumpulan data dan analisis data, yaitu pada tahap proses validasi ahli dan pada tahap validasi empiris atau uji-coba. Sedangkan nama development mengacu pada produk yang dihasilkan dalam proyek penelitian. Penelitian ini adalah penelitian pengembangan. Menurut Borg \& Gall dalam Setyosari (2010:194), penelitian pengembangan adalah penelitian yang berorientasi untuk mengembangkan dan memvalidasi produkproduk yang digunakan dalam pendidikan. Sedangkan menurut Sugiyono (2008:407) metode penelitian dan pengembangan atau dalam bahasa Inggrisnya Research and Development, adalah metode penelitian yang digunakan untuk menghasilkan produk tertentu dan menguji keefektifan produk tersebut. Dalam penelitian ini model yang menjadi acuan adalah model penelitian dan pengembangan oleh Sugiyono (2008:409) dan model prosedural oleh Borg \& Gall dalam Setyosari (2010:205). Langkah-langkah penelitian dan pengembangan dari kedua model tersebut disajikan pada gambar berikut : 


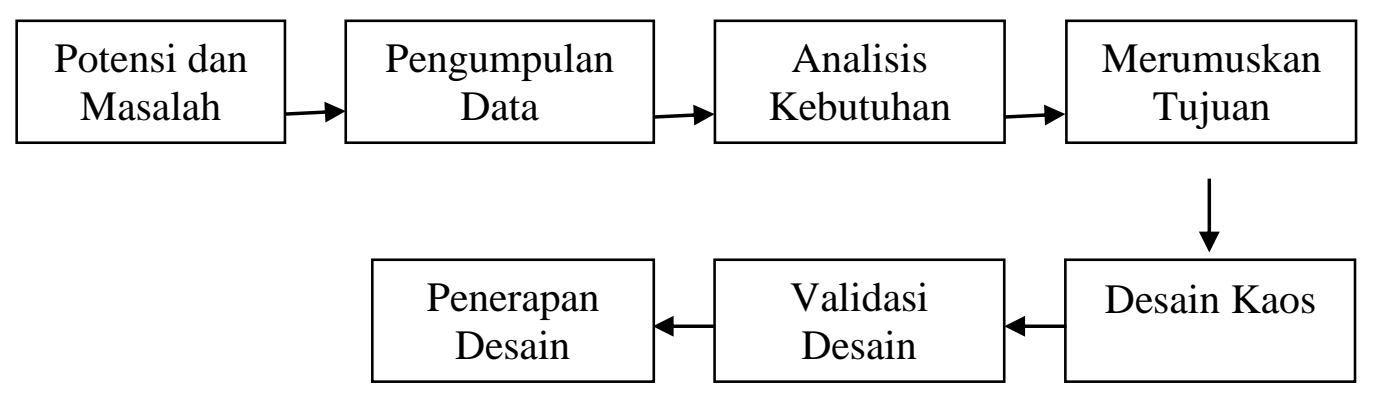

Gambar 1. Model Pengembangan diadaptasi dari Sugiyono (2008:409) dan model prosedural oleh Borg \& Gall dalam Setyosari (2010:205).

\section{Deskripsi Mata Kuliah Grafika}

Tujuan pertama penelitian ini mendeskripsikan ragam seni budaya nusantara karya mahasiswa Prodi Desain Grafis D3 Fakultas Bahasa dan Seni UNESA yang memprogram matakuliah Grafika pada semeseter ganjil tahun ajaran 2013/2014. Jumlah mahasiswa yang mengikuti mata kuliah ini pada semester ganjil 2013/2014 adalah 82 mahasiswa yang dibagi menjadi tiga kelas A, B, dan C. Pada matakuliah Grafika ini kompetensi dasar yang harus dicapai mahasiswa untuk lulus adalah pemahaman terhadap teori-teori grafika secara kritis, analitis dan logis dengan segala aspeknya, meliputi metode, proses, dan penerapannya dalam produksi karya desain grafis

Setelah UTS diharapkan mahasiswa sudah mampu menguasai teori cetak mencetak. Pada pertemuan berikutnya mahasiswa diharapkan sudah praktek merancang desain sablon kemudian menerapkannya pada kaos. Standar kompetensi yang harus dicapai adalah mampu memahami teknik pembuatan acuan cetak saring dan bahan cetak saring. Dari Standar kopetenesi tersebut dipecah menjadi beberapa indikator, yaitu: 1) mampu membuat desain untuk cetak saring, 2) mampu menjelaskan proses pembuatan acuan cetak saring dan 3) mampu menjelaskan alat dan bahan yang digunakan dalam cetak saring

Salah satu tugas yang harus diselesaikan mahasiswa Desain Grafis dalam matakuliah Grafika adalah merancang dan menyablon kaos secara manual sesuai dengan rancangan mereka sendiri. Tugas menyablon tersebut bertemakan Seni Budaya Nusantara. Tema tersebut diterjemahkan mahasiswa sesuai dengan pemikiran masing-masing mahasiswa terhadap seni budaya nusantara tersebut menjadi sebuah konsep desain. Desain sablon yang ditunjukkan harus dapat diterapkan secara teknis pada teknik sablon manual. 
Setelah mengamati karya-karya mahasiswa Desain Grafis yang menempuh mata kuliah Grafika, berdasarkan teori antropologi budaya Koentjningrat berupa tujuh unsurunsur budaya, karya-karya mahasiswa tersebut sebagian besar masuk kedalam unsur kesenian. Kesenian sebagai salah satu unsur budaya dideskripsikan menjadi benda-benda hasil seni. Seni Rupa terlihat pada seni patung, seni ukir atau seni hias pada benda-benda sehari-hari. Deskripsi tersebut memperhatikan bentuk, teknik pembuatan, motif perhiasan dan gaya dari benda-benda kesenian tersebut. Deskripsi seni musik hanya terbatas pada deskripsi alat bunyi-bunyian, sedangkan seni tari hanya menguraikan jalannya tariannya tersebut. Seni drama hanya terbatas pada dongeng yang bisanya berkaitan dengan religi suatu daerah. (Koentjaningrat,2009:298).

Dipandang dari sudut cara kesenian sebagai ekspresi hasrat manusia akan keindahan itu dinikmati, maka ada dua lapangan besar dalam kesenian yaitu: seni rupa yaitu kesenian yang dinikmati oleh manusia dengan mata dan seni suara, yaitu: kesenian yang dinikamti dengan telinga. Dalam lapangan seni rupa terdapat seni patung, seni relief, seni lukis dan gambar. Seni musik ada yang vokal (menyanyi) dan ada yang instrumental (dengan alat bunyi) dan seni sastra yang terdiri dari prosa dan puisi. Lapangan kesenian yang meliputi kedua lapangan tersebut adalah seni tari atau seni gerak karena kesenian ini dapat dinikmati dengan mata maupun telinga. Seni drama (pertunjukan) merupakan kesenian yang meliputi kesemuanya karena mengandung unsur-unsur seni lukis, seni rias, seni musik, seni sastra dan seni tari. Kesemuanya diintegrasikan menjadi satu kebulatan. (Koentjaningrat, 2009:-299).

Menurut Sedyawati $(2006,368)$ pada zaman yang sama di masa budaya Jawa Kuno dari berbagai media ekspresi terdapat kesamaan atau kaidah gaya dan prinsip berungkap. Perbandingannya dapat ditunjukkan sebagai berikut:

1) Prinsip dramatik yang dituangkan kedalam aturan kode fisik yang berkenaan dalam gerak tubuh (tari) yang diuraikan dalam kitab berbahasa Sansekerta ternayata diterapkan dalam penggambaran adegan-adegan reief Candi Prambanan.

2) Kitab yang sama juga menguraikan rincian gerak tari (pada kepala, lengan, tangan, torso, tungkai dan kaki) yang sesuai dengan detail gerak tari di Candi Prambanan dan Candi Borobudur. 
3) Sejumlah karya seni rupa, baik berupa relief pada batu, mangkuk emas maupun benda perunggu tiga dimensi menunjukkan kemungkinan menggunakan gaya ungkap sastra.

Hal ini dapat disimpulkan bahwa kesenian dalam budaya nusantara khususnya Jawa tidak dapat dipisahkan sendiri-sendiri, seni drama, tari, musik dan sastra melainkan menjadi satu kesatuan dalam kesenian. Keterkaitan antara seni pertunjukkan (tari) yang bercerita (drama) terkait erat dengan seni pahat (rupa) yang bercerita di candi. Pada seni teater (drama) dan musik berkaitan erat dengan seni sastra. Pada musik unsur pada sastra ada pada lirik (kidungan) sedangkan pada teater, unsur sastra terletak dialog maupun ungkapan narrator/dalang (Sedyawati, 2006:293-294)

\section{Hasil dan Pembahasan}

1) Reog Ponorogo

Seni Pertunjukan Tradisional diwakili oleh Reog Ponorogo merupakan salah satu kebudayaan di Indonesia yang masih terjaga eksistensinya hingga kini. Kesenian tradisional ini memiliki unsur mistik dan ilmu kebatinan yang kuat. Hal tersebut menjadikan daya tarik tersendiri. Sedangkan Ponorogo merupakan kota yang dianggap sebagai asal kesenian Reog. Pada gerbang kota Ponorogo, terdapat sosok Warok dan Gemblak yang merupakan dua sosok tokoh kesenian Reog yang selalu tampil pada saat pertunjukkan berlangsung (www.kompasiana.com).

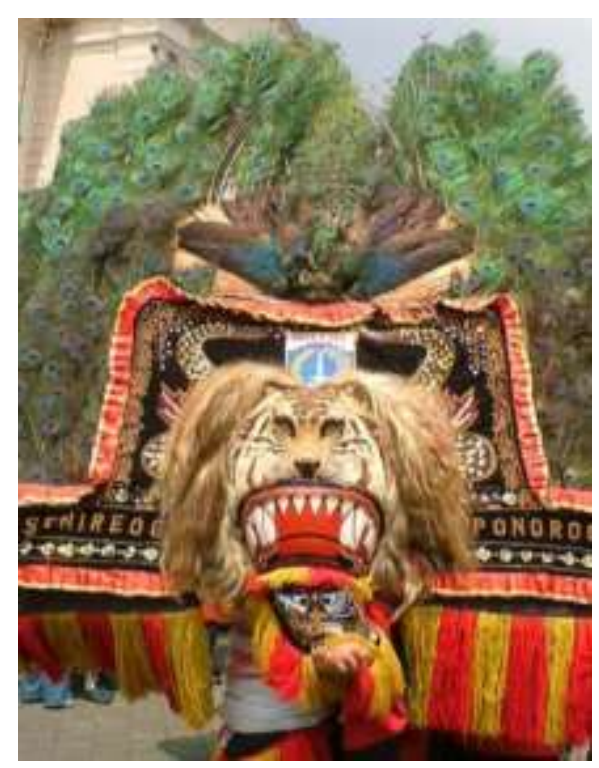

Gambar 2. Singa Barong 
Desain sablon terinspirasi darimotif bulu merak yang terdapat pada Reog Ponorogo. Visualisasi desain sablon berupa 5 (lima) helai burung merak yang ditata simetris. Memiliki 3 (tiga) warna yakni kuning, hijau dan biru sesuai dengan motif bulu merak. Warna biru memberikan kesan dingin dan tenang, percaya diri dan bijaksana. Warna hijau menunjukkan kesuburan dan keseimbangan. Sedangkan warna kuning merujuk pada kebahagiaan, kegembiraan dan kehangatan.

Desain Reog Ponorogo memiliki kelebihan pada keterhubungan yang kuat pada konsep Singa Barong yang merupakan komponen utama ada Reog Ponorogo. Kelebihan lain yang dimiliki desain ini adalah pada pengolahan visual bulu merak secara ikonik bisa terbaca bahwa gambar tersebut merupakan bulu merak. Dilihat dari susunan dan bentuk warnanya mengilustrasikan burung merak sebagai ikon dari Singa Barong yang merupakan bintang utama dari seni pertunjukkan Reog Ponorogo. Hanya saja susunan Bulu merak secara simetris bertumpuk kurang menggambarkan sosok Singa Barong dimana bulu merak simetris tersusun merekah/membuka.

Teks Reog Ponorogo semula lurus dibentuk melengkung mengikuti lengkungan dari bulu-bulu merak agar terlihat serasi dengan bulu-bulu merak tersebut. Warna teks dan bulu-bulu merak tidak dirubah karena sudah cukup mewakili bulu merak pada dadak merak di pertunjukkan Reog. Sebagai penegasan kalau bulu merak pada ilustrasi merupakan bulu pada dadak merak di pertujukkan Reog Ponorogo maka teks Reog Ponorogo tetap dipertahankan dan warna hijau yang sudah serasi tetap dipertahankan. Warna Kaos menggunakan warna hitam untuk memberikan kesan kontras pada warnawarna pada desain yang menggunakan warna cerah (kuning, hijau dan biru). Berikut penerapan desain pada kaos:

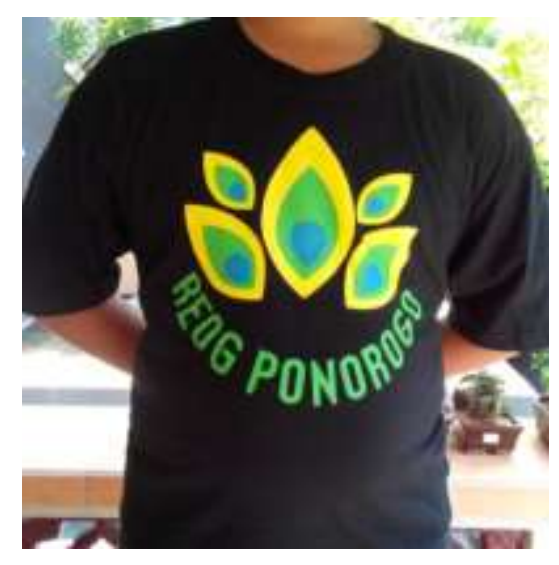

Gambar 3. Penerapan Desain Reog Ponorogo pada Kaos 


\section{2) Topeng Klana}

Seni Rupa Tradisional diwakili oleh Topeng Klana, sebaagai salah satu jenis tari topeng yang berasal dari Cirebon adalah Tari Topeng Klana. Tarian ini merupakan semacam bagian lain dari tari topeng Cirebon lainnya yaitu Tari Topeng Kencana Wungu. Adakalanya kedua tari Topeng ini disajikan bersama, biasa disebut dengan Tari Topeng Klana Kencana Wungu.Tari Topeng Klana merupakan rangkaian gerakan tari yang menceritakan Prabu Minakjingga (Klana) yang tergila-gila pada kecantikan Ratu Kencana Wungu, hingga kemudian berusaha mendapatkan pujaan hatinya. Namun upaya pengejarannya tidak mendapat hasil. Kemarahan yang tak bisa lagi disembunyikannya kemudian membeberkan segala tabiat buruknya. Inilah kiranya yang menginspirasi Nugraha Soeradiredja ketika menciptakan Tari Klana (http://kebudayaanindonesia.net).

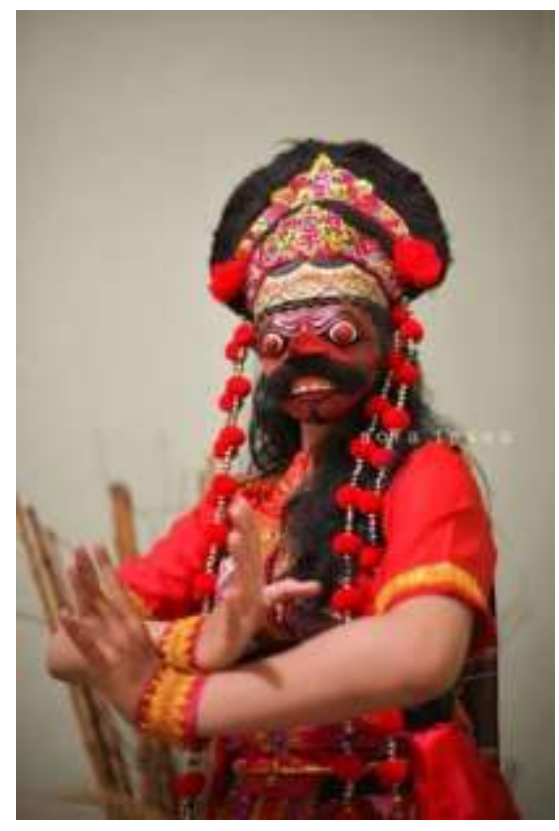

Gambar 4. Penari Topeng Klana

(Sumber: http://sofatessa.blogspot.com/2013/11/tari-topeng-klana.html)

Karakter yang agresif selalu melekat di setiap gerak tarian topeng Klana Cirebon. Karakter yang lincah, energik, keras, penuh hentakan dan bukan hanya itu saja pembawaannya ketika dipanggung sangat berkharisma, gagah perkasa dan penuh dengan ambisi layaknya sosok raja yang haus ambisi duniawi. Dalam bentuk gerak tarian topeng 
Klana selalu memainkan kaki, tangan, pundak, dan hampir kesemua angota badan ikut di gerakan. Ketika menari jarak kaki sebaiknya tidak berubah, gerakan badan harus senada dengan ketukan-ketukan irama musik gamelan. Jika tidak begitu maka tariannya pun dibawakan akan tidak seirama dengan musiknya oleh sebab itu konsentrasi penting sekali dalam menarikan tarian topeng Klana. (http://elib.unikom.ac.id/files/disk1/569/ jbptunikompp-gdl-adelukmann-28437-8-8.uniko-i.pdf)

Menggambarkan karakter Tari Topeng Klana yang berasal dari Jawa Barat dengan ciri khas berkumis, topeng berwarna merah serta mata melotot. Dipilihnya tarian Topeng Klana karena tarian ini sudah tidak dikenali oleh para gernerasi muda. Desain ini bertujuan untuk membangkitkan kembali semangat Tari Topeng Klana melalui kaos. Perwujudan Tari Topeng Klana yaitu menggambarkan angkara murka. Sifat manusia yang serakah dan menghalalkan segala cara untuk mewujudkan ambisinya. Namun Klana kaya raya. Alis dan mata dibuat sdemikian rupa karena sifat tokoh topeng ini murka. Hidung yang panjang serta kumis yang tebal adalah ciri khas topeng ini. Warna yang digunakan dominan merah dan hitam. Menggunakan font Loki Cola karena kaos akan lebih terlihat klasik dan tradsional. Dengan gaya lentur namun tegas memperlihatkan karakter Tari Topeng Klana

Kelebihan desain Topeng Klana ini adalah pada keterhubungan yang kuat pada konsep topeng Klana. Selain itu desian ini juga memiliki kelebihan goresan garis tebal untuk menggambarkan sosok angkara murka sudah terlihat jelas pada alis, mata yang melotot dan kumis yang tertarik ke atas, begitu pula pada hidung yang panjang tajam ke bawah. Hanya saja pada bentuk visual mata topeng sebaiknya tidak menyerupai mata kartun sehingga mengurangi kesan 'sangar'. Tipografi 'Klana' memiliki readability kurang, karena tipis dan berkait sehingga tidak mendukung karakter dari topeng.

Desain Topeng Klana tidak mengalami perubahan yang signifikan, hanya posisi teks “Klana" yang semula di atas dipindah ke bawah dan di tambhakan teks "Topeng" sebagai penegasan bahwa gambar wajah yang ditampilkan adalah sebuah topeng yang bernama Klana. 


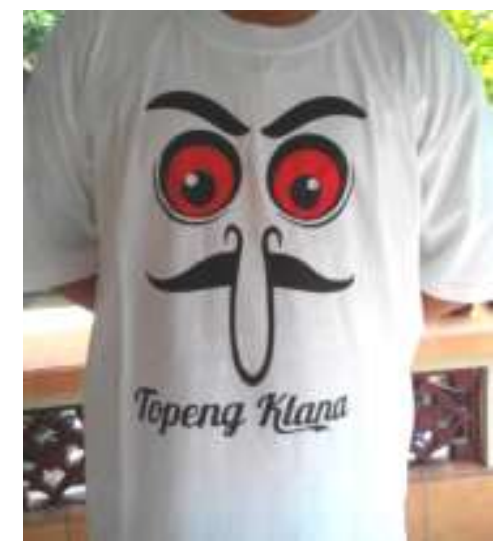

Gambar 5. Penerapan Desain Reog Ponorogo pada Kaos

\section{3) Gasing}

Mainan Tradisional diwakili oleh Gasing merupakan salah satu permainan tradisional Nusantara, walaupun sejarah penyebarannya belum diketahui secara pasti. Di wilayah Pulau Tujuh (Natuna), Kepulauan Riau, permainan gasing telah ada jauh sebelum penjajahan Belanda. Sedangkan di Sulawesi Utara, gasing mulai dikenal sejak 1930-an. Permainan ini dilakukan oleh anak-anak dan orang dewasa. Biasanya, dilakukan di pekarangan rumah yang kondisi tanahnya keras dan datar. Permainan gasing dapat dilakukan secara perorangan ataupun beregu dengan jumlah pemain yang bervariasi, menurut kebiasaan di daerah masing-masing. Hingga kini, gasing masih sangat populer dilakukan di sejumlah daerah di Indonesia. Bahkan warga di kepulauan Rian rutin menyelenggarakan kompetisi. Sementara di Demak, biasanya gasing dimainkan saat pergantian musim hujan ke musim kemarau. Masyarakat Bengkulu ramai-ramai memainkan gasing saat perayaan Tahun Baru Islam, 1 Muharram. (http://id.wikipedia.org/)

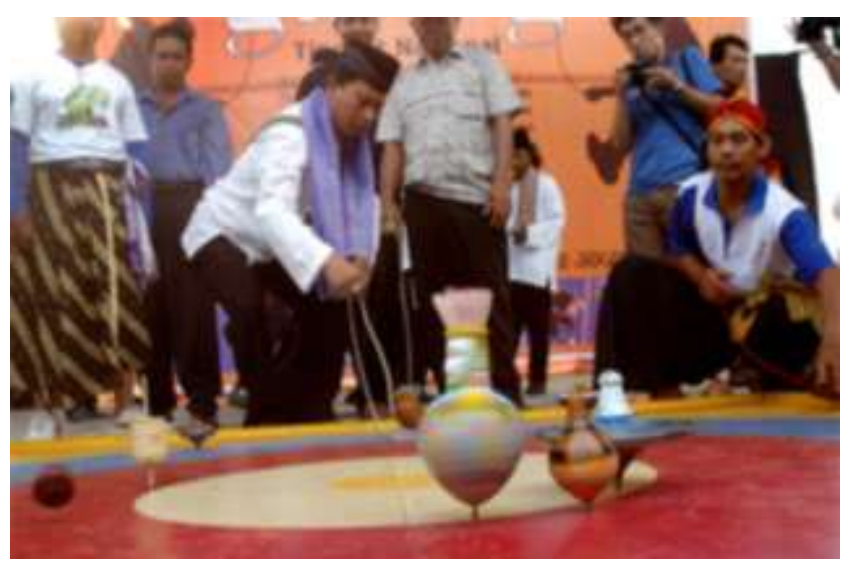




\section{Gambar 6. Permainan Gasing \\ (Sumber: http://postinganbugis.blogspot.com/2013/03/)}

Gasing kayu dibuat dari bahan kayu yang keras, umpamanya dari kayu petai cina, rukam, kemining, jeruk dan lain-lain. Bentuk gasing yang dimainkan berbentuk guci kecil atau menyerupai buah bengkuang. Pada bagian atas diberi kepala untuk melilitkan tali pemutar gasing, pada bagian bawah ditancapkan paku atau besi runcing sebagai taji untuk melukai atau merusak kesembangan gasing lawan. Permainan gasing pada umumnya di tanah keras untuk gasing adu, menggunakan lantai yang licin untuk tahan lamanya berputar. Permainan gasing adu, biasanya dibuat suatu arena tertentu, dilokasi inilah penggasing berkumpul untuk mengadukan gasingnya. Dalam pertandingan gasing yang dinyatakan pemenang adalah gasing yang tahan berputar apabila dipukul lawan dan bila dia memukul lawan jatuh atau mati. Pertandingan ini dilakukan perpasangan yang memang diadu dengan yang menang. (http://kebudayaanindonesia.net).

Dalam desain ini menggambarkan keberadaan gasing senbagai salah satu permainan tradisional nusantara, yaitu: dengan memvisualisasikan gasing secara utuh dan sederhana agar mudah dipahami oleh audiens (masyarakat). Visualisasi gasing sebagai ikon dengan bentuk siluet atau bayangannya saja. Bentuk geometris membingkai gasing sebagai efisiensi desain. Bidang segitiga mengitari gasing memberikan kesan cahaya yang mengitari bangsa dan diharapkan gasing dapat bersinar sepanjang zaman (tidak punah). Teks "BANGGA INDONESIA" memberikan pesan bahwa permainan gasing sebagai permainan tradisional tetap menjadi kebanggaan bangsa Indonesia walaupun dihujani mainan-mainan modern. Teks "GASING" sebagai penjelas bahwa siluet dibelakangnya adalah gambar gasing sedangakan bentuk geometri yang membingkai teks GASING merupakan penekanan teks itu sendiri. Jenis font yang digunakan pada teks adalah NeverSayDie memberikan kesan tegas dan sederhana.

Kelebihan utama pada desain Gasing ini adalah keterhubungan yang kuat desain obyek gasing dengan konsep permaianan gasing yang merupakan komponen utama permaianan gasing. Selain itu kelebihan lainnya dari desain gasing ini adalah terletak pada kesatuan desain. Desain tampak kompak dan menyatu tidak terpecah-pecah. Kekurangan desain Gasing ini pada garis tepi terkesan mengekang/membatasi kebebasan gerak Gasing. 
Kekurangan lainnya pada teks Gasing berupa pita sebaiknya visualisasinya diganti dengan tali yang menggambarkan bahwa Gasing tersebut digerakkan dengan sabetan untaian tali.

Desain "Gasing" mengalami perubahan perubahan pada teks dengan menghilangkan teks GASING dan menghilangkan biang segi enam supaya cahaya yang dipancarkan gasing terlihat. Teks GASING di tengah diganti dengan teks BANGGA INDONESIA. Diharapkan tanpa tulisan Gasing audien mengetahui bahwa bentuk seperti segitiga tersebut adalah bentuk Gasing.

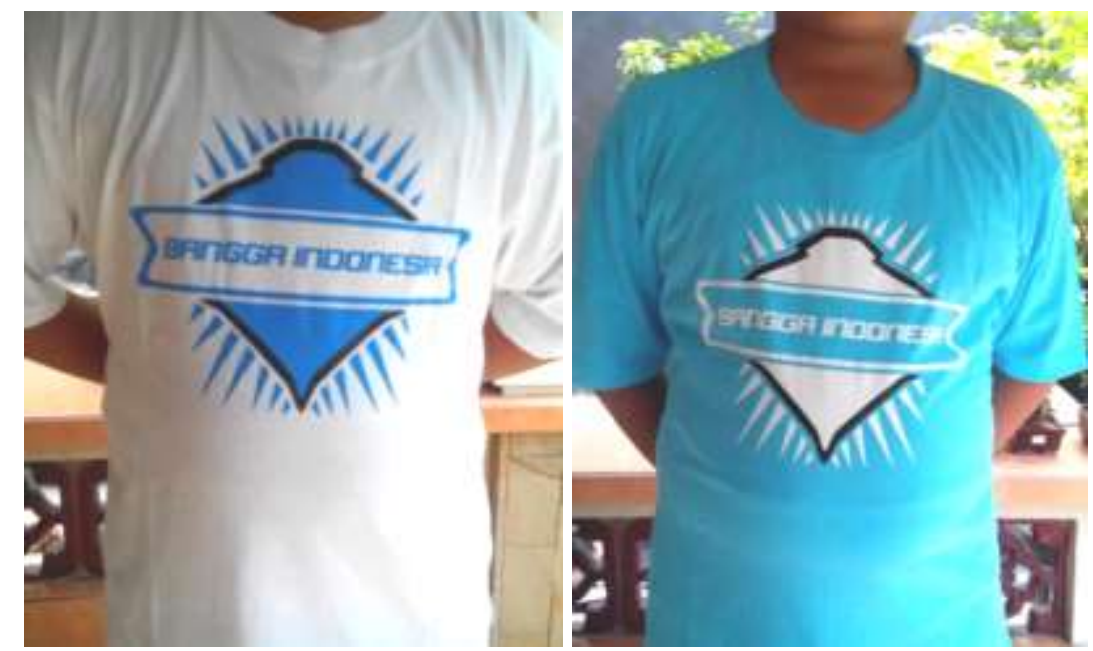

Gambar 7. Penerapan Desain Gasing pada Kaos

\section{4) Sedekah Bumi}

Berbagai macam acara dapat dilakukan untuk mengucapkan rasa syukur kepada Tuhan Yang Maha Esa, atas segala nikmat dan karunia yang diperoleh pada masa kehidupannya. Upacara sedekah laut adalah salah satu perwujudan ungkapan rasa syukur yang dilakukan oleh kelompok masyarakat tertentu. Tradisi sedekah bumi, merupakan salah satu bentuk ritual tradisional masyarakat di Pulau Jawa yang sudah berlangsung secara turun-temurun dari nenek moyang. Upacara tradisi sedekah bumi tersebut umumnya, tidak banyak peristiwa dan kegiatan yang dilakukan di dalamnya. Hanya saja, pada waktu acara tersebut biasanya seluruh masyarakat sekitar yang merayakan tradisi sedekah bumi membuat sesaji dan berkumpul menjadi satu di tempat sesepuh kampung, di balai desa atau tempat-tempat yang telah disepakati oleh seluruh masyarakat setempat 
untuk menggelar acara ritual sedekah bumi tersebut. (http://lib.uinmalang.ac.id/?mod=th_detail\&id=04210060).

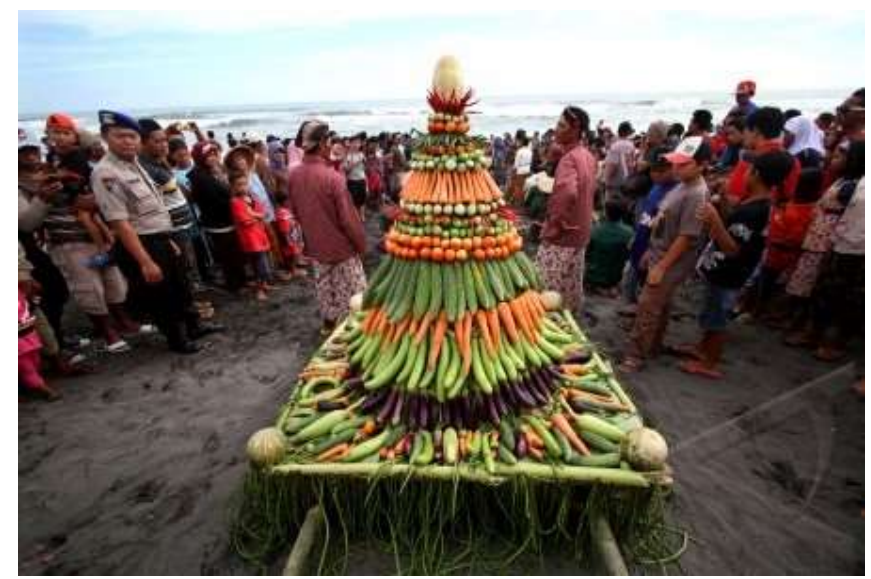

Gambar 8. Tumpeng Sedekah Bumi

Sedekah bumi merupakan salah satu bentuk tradisi masyarakat di pulau Jawa termasuk kota Surabaya yang sudah berlangsung secara turun-temurun dari nenek moyang orang Jawa terdahulu untuk merayakan hasil panen mereka dan juga sebagai bentuk rasa syukur kepada Tuhan Yang Maha kuasa atas limpahan nikmat yang telah diberikan.Namun sekarang di Surabaya, dimana masyarakatnya sudah tidak lagi bermata-pencaharian sebagai petani, sedekah bumi beralih fungsi dari perayaan panen menjadi acara rutin tahunan hal tersebut bertujuan agar tradisi ini tidak punah. Sedekah bumi juga dijadikan moment untuk berkumpul dengan mengundang saudara, teman dan rekan kerja. Sehingga sedekah bumi tidak hanya sebagai bentuk rasa syukur melainkan juga sebagai hiburan untuk masyarakat, hal ini karena dalam tradisi ini terdapat berbagai acara seperti syukuran, okol, tori remo dan juga ludruk.

Kelebihan utama dari desain Tumpeng pada Sedekah Bumi adalah adanya kesatuan antara teks dan ilustrasi. Kelebihan lainnya yang tidak kalah penting adalah keterhubungan yang kuat pada konsep (tumpeng wujud utama pada upacara sedekah bumi. Hanya saja desain visual tumpeng terkesan menyerupai topi/caping petani apabila tidak ada teks penjelas Sedekah Bumi. Sehingga teks Sedekah Bumi memiliki peran penting dalam desain. 
Desain Tumpeng tidak mengalami perubahan yang signifikan, karena secara keseluruhan sudah sesuai dengan prinsip desain dan teknik sablon. Hanya saja teks SEDEKAH BUMI ditata melengkung mengkuti dengan ilustrasi tumpeng. Warnanya juga dibuat hijau lebih cerah mengingat kaos yang akan digunakan adalah gelap (hitam) supaya teks terlihat lebih menonjol. Tujuannya untuk menekankan bahwa ilustrasi tumpeng merupakan visualisasi dari upacara adat sedekah bumi.

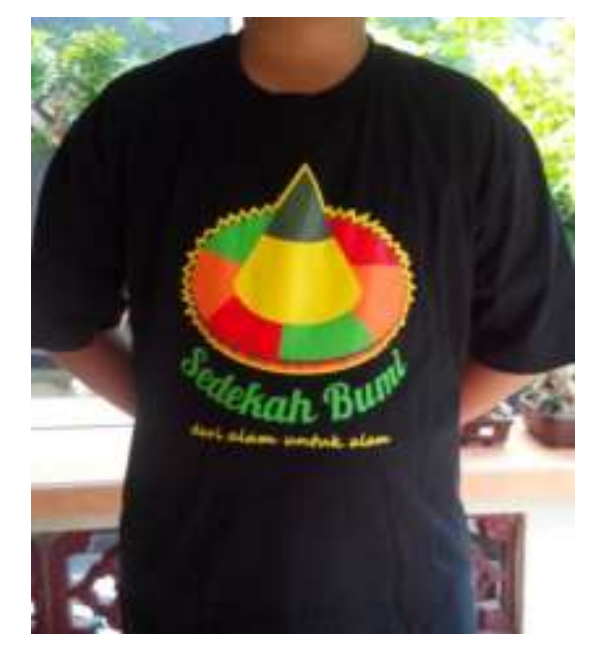

Gambar 9. Penerapan Desain Sedekah Bumi pada Kaos

\section{Penerapan Desain}

Desain akhir yang berjumlah delapan karya diberi komentar oleh desainer grafis yang bergerak di bidang sablon kaos, Azmie Ashar yang juga alumni desain grafis D3 UNESA angkatan 2009 yang menggeluti usaha sablon kaos bernama Kamarduapuluhenam di Jalan Wonocolo I/293e RT 14 RW05 Taman Sidoarjo. Komentar desain berupa wawancara secara detail masing-masing desain ditinjau dari segi desain dan teknik sablon dari kedelapan desain yang dianggap paling layak untuk diterapkan pada kaos. Setelah melalui pertimbangan desain dilihat dari segi komposisi dan eleman desain yang dikaitkan dengan konsep desain maka dipilih empat desain. Empat desain tersebut selain melalui pertimbangan-pertimbangan desain dipertimbangkan pula teknik sablonnya, disesusaikan dengan kemampuan mahasiswa desain grafis yang akan mengampu mata kuliha Grafika. Empat desain tersebut juga melalui sedikit revisi desain tanpa mengubah desain secara substansial. Berikut empat desain yang diterapkan pada kaos. 


\section{Kesimpulan}

Penelitian Perancangan Desain Sablon Kaos Berbasis Seni Budaya Nusantara Pada Mata Kuliah Grafika dapat disimpulkan bahwa: 1) Ragam seni budaya nusantara karya mahasiswa Prodi Desain Grafis UNESA pada matakuliah Grafika dalam penelitian ini dikelompokkan dalam empat tema besar yaitu: seni pertunjukan tradisional, seni rupa tradisional, mainan tradisional, dan upacara adat. 2) Konsep desain sablon kaos berbasis seni budaya nusantara karya mahasiswa Desain Grafis UNESA pada matakuliah Grafika dikelompokkan dalam empat tema besar yaitu: seni pertunjukkan tradisional, seni rupa tradisional, mainan tradisional, dan upacar adat. Seni pertunjukkan tradisional diwakili oleh desain Reog Ponorogo, seni rupa tradisional diwakili oleh Topeng Klana, mainan tradisional diwakili oleh Gasing, seangkan upacara adat diwakili oleh Sedekah Bumi. 3) Desain sablon kaos berbasis seni budaya nusantara beradasarkan karya Mahasiswa Desain Grafis UNESA pada matakuliah Grafika mengalami beberapa perubahan desain disesuaikan dengan prinsip desain dan teknik sablon. 4) Desain kaos dengan teknik sablon yang diterapkan pada kaos adalah Reog Ponorogo, Topeng Klana, Permaianan Gasing dan Sedekah Bumi. Reog Ponorogo menggunaan kaos hitam, Topeng Klana menggunaka kaos putih dan merah, Permaianan Gasing menggunakan kaos putih dan biru sedangkan Sedekah Bumi menggunakan kaos hitam.

\section{Daftar Pustaka}

Gustami,SP., 2007. Butir-Butir Mutiara Estetika Timur, Ide Dasar Penciptaan Seni Kriya Indonesia. Prasista. Yogyakarta

Koentjaningrat. 2009. Ilmu Anthropologi: Pengantar. Jakarta: PT. Rineka Cipta.

Sachari, A. 2002. Estetika: Makna, Simbol dan Daya. Penerbit: ITB. Bandung.

Sedyawati, Edi. 2006. Budaya Indonesia: Kajian Arkeologi, Seni, dan Sejarah. Jakarta: Grafindo.

Setyosari, P. 2010. Metode Penelitian Pendidikan dan Pengembangan. Prenada Media Group. Jakarta.

Sugiyono, 2008. Metode Penelitian Pendidikan Pendekatan Kuantitatif, Kualitatif, dan RED. Alfabeta : Bandung.

Sukmadinata, Nana Syaodih. 2005. Metode Penelitian Pendidikan. Bandung: Remaja Rosdakarya. 